\title{
ANALISA KINERJA KEUANGAN PADA PT. ASTRA INTERNATIONAL TBK PERIODE 2012-2017 DARI SUDUT PANDANG ANALISIS RASIO KEUANGAN DAN METODE DU PONT
}

\author{
Roben Wijaya \\ Program Studi Magister Manajemen Universitas Tarumanagara \\ robenwijaya@yahoo.co.id
}

\begin{abstract}
This study aims to analyze and measure financial performance of PT. Astra International Tbk. using financial ratio analysis and du pont analysis. In conducting the research, data taken from company financial statement from 2012 until 2017. From financial ratio analysis, in liquidity ratio, capital structure ratio, asset management efficiency ratio, profitability ratio and market value ratio indicated if the company has increased every year. From du pont analysis show a continuous increase in Net Profit Margin and Total Asset Turnover every year. This increase is a positive increase so that the financial performance of PT. Astra International in the 2012-2017 period had declined but began to improve starting in 2016 because starting in 2016, the company could manage assets well and efficiently.
\end{abstract}

Abstrak: Penelitian ini bertujuan untuk menganalisa dan mengukur kinerja keuangan dari PT. Astra International Tbk dengan menggunakan analisa rasio keuangan dan analisa du pont. Dalam melakukan penelitian, data yang digunakan diambil dari laporan keuangan perusahaan dari tahun 2012 sampai 2017. Dari analisa rasio keuangan, dapat dilihat bahwa dari sisi liquidity ratio, capital structure ratio, asset management efficiency ratio, profitability ratio serta market value ratio menunjukkan bahwa perusahaan mengalami peningkatan setiap tahunnya. Dari analisa du pont, dapat dilihat bahwa perusahaan menunjukkan peningkatan Net Profit Margin dan Total Asset Turnover terus menerus setiap tahunnya. Peningkatan tersebut adalah peningkatan yang positif sehingga didapat bahwa kinerja keuangan pada PT. Astra International pada periode 2012-2017 sempat menurun namun mulai membaik mulai tahun 2016 karena mulai tahun 2016, perusahaan dapat mengelola asset dengan baik dan efisien.

Keywords: Financial Performance, Finantial Ratio Analysis, Du Pont Analysis.

\section{PENDAHULUAN}

Era globalisasi di dunia usaha semakin berkembang pesat, dimana semakin banyaknya perusahaan-perusahaan baru yang bermunculan, sehingga hal ini menuntut setiap perusahaan untuk dapat meningkatkan daya saingnya agar dapat terus bertahan di dunia bisnis yang semakin hari semakin kompetitif. Salah satu industry yang menarik dengan tingkat kompetisi yang tinggi adalah industri otomotif. Di Indonesia, saat ini sudah terdapat berbagai merek kendaraan dimana setiap merek kendaraan memiliki varian model yang berbeda-beda sehingga dapat memenuhi kebutuhan masing-masing konsumen. Selain merek yang sudah ada lama di Indonesia, terdapat berbagai merek baru yang bermunculan di industry otomotif.

Salah satu perusahaan yang bergerak cukup lama di bidang otomotif adalah PT. Astra International Tbk, dimana perusahaan ini telah hadir di Indonesia selama lebih dari 60 tahun. PT. Astra International Tbk memiliki beberapa lini bisnis perusahaan dimana salah satunya adalah lini bisnis otomotif.

Banyak hal yang harus dipertimbangkan dan strategi harus dilakukan oleh perusahaan untuk mempertahankan perusahaan tersebut sehingga perusahaan tersebut bisa tetap eksis. 
Salah satu hal yang perlu diperhatikan dalam menyusun dan menerapkan strategi yang tepat bagi perusahaan adalah dengan cara memperhatikan dan menganalisa laporan keuangan perusahaan.

Salah satu cara untuk menganalisis laporan keuangan yang lazim digunakan adalah metode analisis rasio untuk mengetahui tingkat likuiditas, struktur kapital, rasio asset, profitabilitas dan rasio pasar dari perusahaan yang telah go public. Selain itu, penulis juga menggunakan metode analisis $D u$ Pont yang digunakan untuk mengetahui faktor-faktor yang mempengaruhi pergerakan Return on Equity suatu perusahaan.

Berdasarkan uraian di atas, maka peneliti tertarik untuk melakukan penelitian dengan judul ”ANALISA KINERJA KEUANGAN PADA PT. ASTRA INTERNATIONAL TBK PERIODE 2012-2017 DARI SUDUT PANDANG ANALISIS RASIO KEUANGAN DAN METODE DU PONT" dengan tujuan yang ingin dicapai adalah:

- Untuk memperoleh gambaran mengenai kinerja perusahaan dengan menggunakan metode analisis rasio keuangan selama 6 tahun yaitu pada tahun 2012-2017.

- Untuk memperoleh gambaran mengenai kinerja perusahaan dengan menggunakan metode Du Pont selama 6 tahun yaitu pada tahun 2012-2017.

\section{Telaah Kepustakaan}

Menurut Harahap (2013), laporan keuangan adalah media informasi yang merangkum semua aktivitas perusahaan jika informasi ini disajikan dengan mebar, maka akan sangat berguna bagi siapa saja dalam pengambilan keputusanmengenai perusahaan yang dilaporkan.

Ikatan Akuntansi Indonesia menyatakan tujuan umum laporan keuangan adalah:

- Untuk memberikan informasi keuangan yang dapat dipercaya mengenai aktiva dan kewajiban serta modal usaha suatu perusahaan.

- Untuk memberikan informasi yang dapat dipercaya mengenai perubahan aktiva bersih suatu perusahaan yang timbul dari kegiatan usaha dalam rangka memperoleh laba.

- Untuk memberikan informasi keuangan yang membantu para pemakai laporan dalam menaksir potensi perusahaan dalam menghasilkan laba.

- Untuk memberikan informasi penting lainnya mengenai perubahan dalam aktiva dan kewajiban suatu perusahaan, seperti informasi mengenai aktivitas pembiayaan dan investasi.

- Untuk mengungkapkan sejauh mungkin informasi lain yang berhubungan dengan laporan keuangan yang relevan untuk kebutuhan pemakai laporan, seperti informasi mengenai kebijakan akuntansi yang dianut perusahaan.

Menurut Titman, Keown dan Martin (2014, p.52) ada 4 bentuk laporan keuangan yang dihasilkan dari suatu perusahaan:

- Laporan laba rugi (Income Statement)

Laporan laba rugi berisi jumlah penghasilan yang telah didapatkan oleh suatu perusahaan selama jangka waktu tertentu, biasanya dibagi menjadi dalam 3 bulan atau full 1 tahun. Laporan laba rugi juga berisikan pengeluaran yang telah dikeluarkan oleh perusahaan dalam periode tertentu untuk mendapatkan laba suatu perusahaan.

- Neraca keuangan (Balance Sheet)

Neraca keuangan berisikan tanggal dari suatu perusahaan mendapatkan suatu asset, kewajiban yang harus dikeluarkan oleh perusahaan dan ekuitas pemegang saham. 
- $\quad$ Laporan arus kas (Cash Flow Statement)

Laporan arus kas berisi tentang jumlah uang yang diterima dan jumlah uang yang dikeluarkan uleh perusahaan dalam periode waktu tertentu, biasanya dalam waktu 3 bulan atau full 1 tahun,

- Laporan ekuitas pemegang saham (Statement of shareholders' equity)

Laporan ekuitas pemegang saham berisi akun rinci dari aktivitas perusahaan di dalam saham biasa dan saham preferred.

Menurut Munawir (2014), laporan keuangan memiliki keterbatasan yaitu:

- Laporan keuangan bersifat historis, yaitu merupakan laporan atas kejadian yang lewat. Karenanya laporan keuangan tidak dianggap sebagai satu-satunya sumber informasi dalam proses pengambilan keputusan ekonomi.

- Laporan keuangan bersifat umum, disajikan untuk pemakai dan bukan dimaksudkan untuk memenuhi kebutuhan tertentu saja, misalnya untuk Pajak dan Bank.

- Proses penyusunan laporan keuangan tidak luput dari penggunaan taksiran dan berbagai pertimbangan.

- Akutansi hanya melaporkan informasi material. Demikian pula penerapan prinsip akutansi terhadap suatu fakta atau pos tertentu mungkin tidak dilaksanakan jika hal ini dianggap tidak material atau tidak menimbulkan pengaruh yang material terhadap laporan keuangan.

- Laporan keuangan bersifat konservatif dalam menghadapi ketidakpastian, bila terdapat beberapa kemungkinan kesimpulan yang tidak pasti mengenai penilaian beberapa suatu pos, maka lazimnya dipilih alternatif yang menghasilkan laba bersih atau nilai aktiva paling kecil.

- Laporan keuangan menekankan pada makna ekonomis suatu peristiwa atau transaksi daripada bentuk hukumnya (formalitas), (substance over form).

- Laporan keuangan dengan menggunakan istilah-istilah teknis dan pemakai laporan keuangan diasumsikan memahami bahasa teknis akutansi dan sifat dari informasi yang diharapkan.

- Adanya berbagai alternatif metode akutansi yang digunakan menimbulkan variasi dalam pengukuran sumber-sumber ekonomis dan tingkat kesuksesan antar perusahaan.

- Informasi yang bersifat kualitatif dan fakta yang tidak dapat dikuantifikasikan umumnya diabaikan.

Menurut Munawir (2014) analisis rasio adalah suatu metode analisa untuk mengetahui hubungan dari pos-pos tertentu dalam neraca atau laporan rugi laba secara individu atau kombinasi dari kedua laporan tersebut. Analisis rasio digunakan karena dengan cara ini, akan diperoleh perbandingan yang lebih bermanfaat daripada melihat angka.

\section{METODE PENELITIAN}

Data penelitian yang dilakukan adalah dengan menggunakan laporan keuangan tahunan perusahaan yang telah diaudit pada periode 2012 sampai 2017. Dalam melakukan analisis, metode yang digunakan adalah metode analisis rasio dan metode $d u$ pont.

Jenis - jenis analisis rasio keuangan menurut Keown (2014):

- Liquidity Ratio, merupakan analisa kemampuan perusahaan untuk membayar tepat waktu dan seberapa cepat perusahaan mencairkan aktivanya (piutang usaha dan persediaan) ke 
dalam uang tunai. Untuk menilai posisi keuangan jangka pendek (likuiditas), terdapat

beberapa rasio yang dapat digunakan yaitu:

Current Ratio adalah rasio yang menunjukkan likuiditas perusahaan yang diukur dengan membandingkan aktiva lancar terhadap hutang lancar. Rumus Current Ratio:

$$
\text { Current Ratio }=\frac{\text { Current Assets }}{\text { Current Liabilities }}
$$

Acid-Test Ratio adalah rasio yang menunjukkan likuiditas perusahaan yang diukur dengan membandingkan aktiva lancar, kecuali persediaan, terhadap kewajiban lancarnya. Rumus Acid-Test Ratio:

$$
\text { Acid Test Ratio }=\frac{\text { Current Assets }- \text { Inventory }}{\text { Current Liabilities }}
$$

Average Collection Period menandakan seberapa cepat perusahaan menagih kreditnya yang diukur dari rata-rata jumlah hari penagihan piutang dagang. Rumus Average Collection Period:

$$
\text { Average Collection Period }=\frac{\text { Account receivable }}{\text { Annual Credit Sales } / 365}
$$

Account Receivable Turnover menunjukkan seberapa cepat perusahaan menagih kreditnya yang diukur dari lamanya waktu piutang dagang ditagih atau perputaran piutang usaha selama tahun tersebut. Rumus Account Receivable Turnover:

$$
\text { Account Receivable Turnover }=\frac{\text { Account Credit Sales }}{\text { Account Receivable }}
$$

Inventory Turnover menandakan likuiditas relative persediaan yang diukur dengan berapa kali penggantian persediaan perusahaan selama tahun tersebut. Rumus Inventory Turnover:

$$
\text { Inventory Turnover }=\frac{\text { Cost of Goods Sold }}{\text { Inventories }}
$$

Capital Structure Ratio, merupakan rasio yang menggambarkan kemampuan perusahaan dalam memenuhi seluruh kewajibannya. Sama halnya dengan liquidity ratio, capital structure ratio juga diperlukan untuk kepentingan analisis kredit atau analisis resiko keuangan. Untuk menilai capital structure ratio, terdapat beberapa rasio yang dapat digunakan yaitu:

Debt Ratio merupakan rasio yang menunjukkan berapa banyak hutang yang digunakan untuk membiayai aset-aset perusahaan. Rumus Debt Ratio:

$$
\text { Debt Ratio }=\frac{\text { Total Liabilities }}{\text { Total Assets }}
$$

Time Interest Earned merupakan rasio yang menunjukkan kemampuan perusahaan untuk menutupi biaya bunga yang diukur dengan membandingkan pendapatan sebelum bunga dan pajak-pajak terhadap biaya bunga. Rumus Time Interest Earned:

$$
\text { Time Interest Earned }=\frac{\text { Net Operation Income or EBIT }}{\text { Interest Expense }}
$$

Asset Management Efficiency Ratio merupakan rasio yang digunakan untuk mengukur seberapa efektif penggunaan aset yang dimiliki oleh suatu perusahaan untuk menghasilkan penjualan. Untuk menilai asset management efficiency ratio, terdapat beberapa rasio yang dapat digunakan yaitu: 
- Total Asset Turnover merupakan rasio yang digunakan untuk mengukur berapa jumlah penjualan yang akan dihasilkan dari setiap rupiah dana yang tertanam dalam total aset. Rumus Total Asset Turnover:

$$
\text { Total Asset Turnover }=\frac{\text { Sales }}{\text { Total Assets }}
$$

- Fixed Asset Turnover merupakan rasio yang digunakan untuk mengukur keefektifan aset tetap yang dimiliki perusahaan dalam menghasilkan penjualan. Rumus Fixed Asset Turnover:

$$
\text { Fixed Asset Turnover }=\frac{\text { Sales }}{\text { Net Plant and Equipment }}
$$

Profitability Ratio merupakan rasio yang menggambarkan kemampuan perusahaan dalam menghasilkan laba. Untuk menilai profitability ratio, terdapat beberapa rasio yang dapat digunakan yaitu:

- Net Profit Margin merupakan rasio yang menunjukkan keefektifan manajemen dalam mengelola laporan keuangan perusahaan yang diukur dengan membandingkan laba usaha terhadap penjualan. Rumus Net Profit Margin:

$$
\text { Net Profit Margin }=\frac{\text { Net Income }}{\text { Sales }}
$$

- Return on Assets merupakan rasio yang menunjukkan hasil pengembalian atas penggunaan aset perusahaan dalam mencuptakan laba bersih. Dengan kata lain, rasio ini digunakan untuk mengukur seberapa besar jumlah laba bersih yang akan dihasilkan dari setiap rupiah dana yang tertanam dalam total aset. Rumus Return on Assets:

$$
\text { Return on Assets }=\frac{\text { Net Operation Income or EBIT }}{\text { Total Assets }}
$$

- Return on Equity merupakan rasio yang menunjukkan hasil pengembalian atas penggunaan ekuitas perusahaan dalam menciptakan laba bersih. Dengan kata lain, rasio ini digunakan untuk mengukur seberapa besar jumlah laba bersih yang akan dihasilkan dari setiap rupiah dana yang tertanam dalam total ekuitas. Rumus Return on Equity:

$$
\text { Return on Equity }=\frac{\text { Net Income }}{\text { Common Equity }}
$$

Market Value Ratio merupakan rasio yang digunakan untuk mengestimasi nilai intrinsic perusahaan (nilai saham). Untuk menilai market value ratio, terdapat beberapa rasio yang dapat digunakan yaitu:

- $\quad$ Price-Earnings Ratio merupakan rasio yang menunjukkan hasil perbandingan antara harga pasar per lembar saham dengan laba per lembar saham. Melalui rasio ini, harga saham sebuah emiten dibandingkan dengan laba bersih yang dihasilkan oleh emiten tersebut dalam setahun. Rumus Price-Earnings Ratio:

$$
\text { Price Earning Ratio }=\frac{\text { Market Price per Share }}{\text { Earning per Share }}
$$

- $\quad$ Market-to-Book Ratio merupakan rasio yang menunjukkan hasil perbandingan antara harga pasar per lembar saham dengan nilai buku per lembar saham. Rasio ini 
digunakan untuk mengukur tingkat harga saham apakah overvalued atau undervalued.

Rumus Market-to-Book Ratio:

$$
\text { Market to Book Ratio }=\frac{\text { Market Price per Share }}{\text { Book Value per Share }}
$$

Analisis Du Pont.

Pada tahun 1919, The Du Pont Company memulai untuk menggunakan pendekatan analisis rasio untuk mengevaluasi efektivitas dari perusahaan. Salah satu kegunaan Du Pont yang prinsipil adalah sifatnya yang menyeluruh. Salah satu variasi yang digunakan dalam pendekatan Du Pont adalah memisahkan ROE (Return on Equity) menjadi 3 bagian.

$R O E=$ Net Profit Margin $x$ Total Asset Turnover $x$ Equity Multiplier

$$
\text { ROE }=\frac{\text { Net Income }}{\text { Sales }} \times \frac{\text { Sales }}{\text { Total Assets }} \times \frac{1}{1-\text { Debt Ratio }}
$$

\section{HASIL DAN PEMBAHASAN}

Analisis Rasio Keuangan

\begin{tabular}{|c|c|c|c|c|c|c|c|}
\hline Ratio & 2012 & 2013 & 2014 & 2015 & 2016 & 2017 & $\begin{array}{l}\text { Rata- } \\
\text { rata }\end{array}$ \\
\hline \multicolumn{8}{|c|}{ Liquidity Ratio } \\
\hline Current Ratio (kali) & 1.40 & 1.24 & 1.32 & 1.38 & 1.24 & 1.23 & 1.30 \\
\hline Quick Ratio (kali) & 1.12 & 1.04 & 1.09 & 1.14 & 1.04 & 1.03 & 1.08 \\
\hline $\begin{array}{l}\text { Average Collection } \\
\text { Period (hari) }\end{array}$ & 89.85 & 97.23 & 99.09 & 105.03 & 113.13 & 108.89 & 102.20 \\
\hline $\begin{array}{l}\text { Account Receivables } \\
\text { turnover (kali) }\end{array}$ & 4.06 & 3.75 & 3.68 & 3.48 & 3.23 & 3.35 & 3.59 \\
\hline $\begin{array}{l}\text { Inventory Turnover } \\
\text { (kali) }\end{array}$ & 9.93 & 10.99 & 9.59 & 8.04 & 8.14 & 8.39 & 9.18 \\
\hline \multicolumn{8}{|c|}{ Capital Structure Ratio } \\
\hline Debt Ratio (\%) & $50.73 \%$ & $50.38 \%$ & $49.08 \%$ & $48.45 \%$ & $46.57 \%$ & $47.12 \%$ & $48.72 \%$ \\
\hline $\begin{array}{l}\text { Time Interest Earned } \\
\text { Ratio (kali) }\end{array}$ & 27.32 & 24.82 & 19.68 & 14.33 & 12.75 & 14.30 & 18.87 \\
\hline \multicolumn{8}{|c|}{ Asset Management Efficiency Ratio } \\
\hline $\begin{array}{l}\text { Total Asset Turnover } \\
\text { (kali) }\end{array}$ & 1.03 & 0.91 & 0.85 & 0.75 & 0.69 & 0.70 & 0.82 \\
\hline $\begin{array}{l}\text { Fixed Asset } \\
\text { Turnover (kali) }\end{array}$ & 5.94 & 5.37 & 5.10 & 4.44 & 4.26 & 4.50 & 4.94 \\
\hline \multicolumn{8}{|c|}{ Profitability Ratio } \\
\hline $\begin{array}{l}\text { Net Profit Margin } \\
(\%)\end{array}$ & $12.09 \%$ & $11.50 \%$ & $10.97 \%$ & $8.48 \%$ & $10.11 \%$ & $11.24 \%$ & $10.73 \%$ \\
\hline Return on Assets (\%) & $15.31 \%$ & $12.86 \%$ & $11.46 \%$ & $8.00 \%$ & $8.50 \%$ & $9.88 \%$ & $11.00 \%$ \\
\hline Return on Equity (\%) & $31.06 \%$ & $25.92 \%$ & $22.51 \%$ & $15.51 \%$ & $15.91 \%$ & $18.68 \%$ & $21.60 \%$ \\
\hline \multicolumn{8}{|c|}{ Market Value Ratio } \\
\hline $\begin{array}{l}\text { Price-Earning Ratio } \\
\text { (kali) }\end{array}$ & 15.31 & 14.17 & 15.66 & 16.81 & 22.13 & 17.81 & 16.98 \\
\hline $\begin{array}{l}\text { Market to book ratio } \\
\text { (kali) }\end{array}$ & 3.31 & 2.59 & 2.50 & 1.92 & 2.39 & 2.15 & 2.48 \\
\hline
\end{tabular}

Dari analisis rasio keuangan PT. Astra International Tbk., didapat data sebagai berikut: 
Sumber : Annual report PT. Astra International Tbk., data diolah, periode 2012-2017.

- $\quad$ Liquidity Ratio

\section{$>$ Current ratio}

Selama periode 2012-2017, current ratio PT. Astra International mengalami kenaikan dengan rata-rata 1.30 kali. Pada tahun 2013 current ratio mengalami penurunan sebesar 11.23\% dibandingkan tahun 2012. Pada tahun 2014 current ratio mengalami kenaikan sebesar 6.49\% dibandingkan tahun. Pada tahun 2015 current ratio mengalami sedikit kenaikan yaitu sebesar $4.29 \%$ dibandingkan tahun 2014. Pada tahun 2016 current ratio mengalami penurunan sebesar $10.14 \%$ dibandingkan tahun 2015. Pada tahun 2017 current ratio kembali mengalami penurunan namun tidak terlalu signifikan, yaitu sebesar $0.87 \%$ dibandingkan tahun 2016. Hal ini menunjukkan bahwa likuiditas perusahaan paling likuid di tahun 2013.

\section{- Acid-test ratio}

Selama periode 2012-2017, acid-test ratio PT. Astra International mengalami kenaikan dengan rata-rata 1.08 kali. Pada tahun 2013 acid-test ratio mengalami penurunan sebesar 6.97\% dibandingkan tahun 2012. Pada tahun 2014 acid-test ratio mengalami peningkatan sebesar $5.05 \%$ dibandingkan tahun 2013. Pada tahun 2015 acid-test ratio mengalami sedikit kenaikan yaitu sebesar $4.33 \%$ dibandingkan tahun 2014. Pada tahun 2016 acid-test ratio mengalami penurunan dibandingkan tahun 2015 yaitu sebesar 8.69\%. Pada tahun 2017 acid-test ratio kembali mengalami sedikit penurunan dibandingkan tahun 2016 yaitu sebesar $0.85 \%$. Hal ini menunjukkan bahwa likuiditas perusahaan paling likuid di tahun 2013.

$>$ Average collection period

Selama periode 2012-2017, average collection period PT. Astra International mengalami kenaikan dengan rata-rata 102.20 hari. Pada tahun 2013 average collection period mengalami kenaikan sebesar 8.21\% dibandingkan tahun 2012. Pada tahun 2014 average collection period mengalami kenaikan sebesar $1.92 \%$ dibandingkan tahun 2013. Pada tahun 2015 average collection period mengalami kenaikan sebesar 6.00\% dibandingkan tahun 2014. Pada tahun 2016 average collection period mengalami kenaikan sebesar $7.71 \%$ dibandingkan tahun 2015 . Pada tahun 2017 average collection period mengalami penurunan sebesar $3.75 \%$ dibandingkan tahun 2016. Hal ini menunjukkan semakin tahun, rata-rata waktu yang diperlukan perusahaan untuk menagih kreditnya semakin lama.

$>$ Account receivables turnover

Selama periode 2012-2017, account receivable turnover PT. Astra International mengalami kenaikan dengan rata-rata 3.59 kali. Pada tahun 2013 account receivable turnover mengalami penurunan sebesar $7.59 \%$ dibandingkan tahun 2012. Pada tahun 2014 account receivable turnover mengalami sedikit penurunan sebesar $1.88 \%$ dibandingkan tahun. Pada tahun 2015 account receivable turnover mengalami penurunan sebesar 5.66\% dibandingkan tahun 2014. Pada tahun 2016 account receivable turnover kembali mengalami penurunan sebesar $7.16 \%$ dibandingkan tahun 2015. Pada tahun 2017 account receivable turnover mengalami kenaikan sebesar 3.89\% dibandingkan tahun 2016. Hal ini menunjukkan semakin tahun, rata-rata waktu yang diperlukan perusahaan untuk menagih kreditnya semakin lama. 


\section{Inventory turnover}

Selama periode 2012-2017, inventory turnover PT. Astra International mengalami kenaikan dengan rata-rata 9.18 kali. Pada tahun 2013 inventory turnover mengalami kenaikan sebesar 10.59\% dibandingkan tahun 2012. Pada tahun 2014 inventory turnover mengalami penurunan sebesar $12.71 \%$ dibandingkan tahun 2013. Pada tahun 2015 inventory turnover kembali mengalami penurunan sebesar 16.13\% dibandingkan tahun 2014. Pada tahun 2016 inventory turnover mengalami kenaikan sebesar 1.20\% dibandingkan tahun 2015. Pada tahun 2017 inventory turnover mengalami kenaikan sebesar $3.11 \%$ dibandingkan tahun 2016. Hal ini menunjukkan bahwa mulai tahun 2015, barang yang dijual semakin tahun semakin banyak.

\section{- $\quad$ Capital Structure Ratio}

\section{$>$ Debt ratio}

Selama periode 2012-2017, debt ratio PT. Astra International mengalami kenaikan dengan rata-rata 48.72\%. Pada tahun 2013 debt ratio mengalami penurunan sebesar $0.69 \%$ dibandingkan tahun 2012. Pada tahun 2014 debt ratio kembali mengalami penurunan sebesar $2.58 \%$ dibandingkan tahun 2013. Pada tahun 2015 debt ratio kembali mengalami penurunan sebesar $1.29 \%$ dibandingkan tahun 2014. Pada tahun 2016 debt ratio kembali mengalami penurunan sebesar $3.87 \%$ dibandingkan tahun. Pada tahun 2017 debt ratio mengalami kenaikan sebesar $1.18 \%$ dibandingkan tahun 2016. Hal ini menunjukkan hampir $1 / 2$ dari aset perusahaan dibiayai dari hutang.

$>$ Time interest earned ratio

Selama periode 2012-2017, time interest earned ratio PT. Astra International mengalami kenaikan dengan rata-rata 18.87\%. Pada tahun 2013 time interest earned ration mengalami penurunan sebesar 9.17\% dibandingkan tahun 2012 . Pada tahun 2014 time interest earned ratio mengalami penurunan yang lumayan besar yaitu sebesar $20.71 \%$ dibandingkan tahun. Pada tahun 2015 time interest earned ratio kembali mengalami penurunan sebesar $27.19 \%$ dibandingkan tahun 2014. Pada tahun 2016 time interest earned ratio kembali mengalami penurunan sebesar $11.00 \%$ dibandingkan tahun 2015. Pada tahun 2017 time interest earned ratio mengalami kenaikan sebesar $12.12 \%$ dibandingkan tahun 2016 . Hal ini menunjukkan bahwa kemampuan perusahaan untuk membayar bunga mulai naik di tahun 2017.

- $\quad$ Asset Management Efficiency Ratio

$>$ Total asset turnover

Selama periode 2012-2017, total asset turnover PT. Astra International mengalami kenaikan dengan rata-rata 0.82 kali. Pada tahun 2013 total asset turnover mengalami penurunan sebesar $12.18 \%$ dibandingkan tahun 2012. Pada tahun 2014 total asset turnover mengalami penurunan sebesar $5.68 \%$ dibandingkan tahun 2013. Pada tahun 2015 total asset turnover kembali mengalami penurunan sebesar 12.18\% dibandingkan tahun 2014. Pada tahun 2016 total asset turnover kembali mengalami penurunan sebesar $7.85 \%$ dibandingkan tahun 2015. Pada tahun 2017 total asset turnover mengalami kenaikan sebesar $0.79 \%$ dibandingkan tahun 2016. Hal ini menunjukkan bahwa kemampuan perusahaan untuk menghasilkan uang dari total aset yang dimiliki baru mengalami peningkatan di tahun 2017. 
Fixed asset turnover

Selama periode 2012-2017, fixed asset turnover PT. Astra International mengalami kenaikan dengan rata-rata 4.94 kali. Pada tahun 2013 fixed asset turnover mengalami penurunan sebesar 9.58\% dibandingkan tahun 2012. Pada tahun 2014 fixed asset turnover mengalami penurunan sebesar $5.07 \%$ dibandingkan tahun 2013. Pada tahun 2015 fixed asset turnover mengalami penurunan sebesar 12.91\% dibandingkan tahun 2014. Pada tahun 2016 fixed asset turnover mengalami penurunan sebesar $3.99 \%$ dibandingkan tahun 2015. Pada tahun 2017 fixed asset turnover mengalami penurunan sebesar 5.47\% dibandingkan tahun 2016. Hal ini menunjukkan bahwa kemampuan perusahaan untuk menghasilkan uang dari aset tetap yang dimiliki baru mengalami peningkatan di tahun 2017.

\section{- $\quad$ Profitability Ratio}

\section{$>$ Net profit margin}

Selama periode 2012-2017, net profit margin PT. Astra International mengalami kenaikan dengan rata-rata $10.73 \%$. Pada tahun 2013 net profit margin mengalami penurunan sebesar 4.90\% dibandingkan tahun 2012. Pada tahun 2014 net profit margin mengalami penurunan sebesar $4.62 \%$ dibandingkan tahun 2013. Pada tahun 2015 net profit margin mengalami penurunan yang lumayan besar yaitu sebesar 22.73\% dibandingkan tahun 2014. Pada tahun 2016 net profit margin mengalami kenaikan lumayan besar yaitu sebesar $19.24 \%$ dibandingkan tahun 2015. Pada tahun 2017 net profit margin kembali mengalami kenaikan sebesar $11.23 \%$ dibandingkan tahun 2016. Hal ini menunjukkan bahwa perusahaan mendapatkan peningkatan keuntungan mulai pada tahun 2016.

$>$ Return on assets

Selama periode 2012-2017, return on assets PT. Astra International mengalami kenaikan dengan rata-rata $11 \%$. Pada tahun 2013 return on assets mengalami penurunan sebesar $15.97 \%$ dibandingkan tahun 2012. Pada tahun 2014 return on assets kembali mengalami penurunan sebesar $10.87 \%$ dibandingkan tahun 2013 . Pada tahun 2015 return on assets kembali mengalami penurunan lumayan besar yaitu sebesar $30.23 \%$ dibandingkan tahun 2014. Pada tahun 2016 return on assets mengalami kenaikan sebesar 6.25\% dibandingkan tahun 2015. Pada tahun 2017 return on assets kembali mengalami kenaikan sebesar $16.20 \%$ dibandingkan tahun 2016. Hal ini menunjukkan bahwa perusahaan mendapatkan peningkatan keuntungan dari aset yang dimiliki mulai pada tahun 2016.

\section{$>$ Return on equity}

Selama periode 2012-2017, return on equity PT. Astra International mengalami kenaikan dengan rata-rata $21.60 \%$. Pada tahun 2013 return on equity mengalami penurunan sebesar $16.56 \%$ dibandingkan tahun 2012. Pada tahun 2014 return on equity mengalami penurunan sebesar $13.14 \%$ dibandingkan tahun 2013. Pada tahun 2015 return on equity mengalami penurunan sebesar $31.09 \%$ dibandingkan tahun 2014. Pada tahun 2016 return on equity mengalami kenaikan sebesar $2.53 \%$ dibandingkan tahun 2015. Pada tahun 2017 return on equity mengalami kenaikan sebesar $17.42 \%$ dibandingkan tahun 2016. Hal ini menunjukkan bahwa perusahaan mendapatkan peningkatan keuntungan dari ekuitas yang dimiliki mulai pada tahun 2016 . 
- $\quad$ Market Value Ratio

$>$ Price earning ratio

Selama periode 2012-2017, price earning ratio PT. Astra International mengalami kenaikan dengan rata-rata 16.98\%. Pada tahun 2013 price earning ratio mengalami penurunan sebesar 7.48\% dibandingkan tahun 2012. Pada tahun 2014 price earning ratio mengalami kenaikan sebesar $10.57 \%$ dibandingkan tahun 2013. Pada tahun 2015 price earning ratio mengalami kenaikan sebesar $7.29 \%$ dibandingkan tahun 2014. Pada tahun 2016 price earning ratio mengalami kenaikan sebesar $31.65 \%$ dibandingkan tahun 2015. Pada tahun 2017 price earning ratio mengalami penurunan sebesar $19.50 \%$ dibandingkan tahun 2016.

Market to book ratio

Selama periode 2012-2017, market to book ratio PT. Astra International Tbk mengalami kenaikan dengan rata-rata 2.48\%. Pada tahun 2013 market to book ratio mengalami penurunan sebesar $21.75 \%$ dibandingkan tahun 2012. Pada tahun 2014 market to book ratio mengalami penurunan sebesar $3.53 \%$ dibandingkan tahun 2013. Pada tahun 2015 market to book ratio mengalami penurunan sebesar 23.24\% dibandingkan tahun 2014. Pada tahun 2016 market to book ratio mengalami kenaikan sebesar 24.73\% dibandingkan tahun 2015. Pada tahun 2017 market to book ratio mengalami penurunan sebesar $10.24 \%$ dibandingkan tahun 2016.

- Analisis Du Pont

Dari analisis rasio keuangan PT. Astra International Tbk., didapat data sebagai berikut:

\begin{tabular}{|l|c|c|c|c|c|c|c|}
\hline \multicolumn{1}{|c|}{ Du Pont } & $\mathbf{2 0 1 2}$ & $\mathbf{2 0 1 3}$ & $\mathbf{2 0 1 4}$ & $\mathbf{2 0 1 5}$ & $\mathbf{2 0 1 6}$ & $\mathbf{2 0 1 7}$ & $\begin{array}{c}\text { Rata- } \\
\text { rata }\end{array}$ \\
\hline $\begin{array}{l}\text { Net Profit Margin } \\
(\%)\end{array}$ & $12.09 \%$ & $11.50 \%$ & $10.97 \%$ & $8.48 \%$ & $10.11 \%$ & $11.24 \%$ & $10.73 \%$ \\
\hline $\begin{array}{l}\text { Total Asset Turnover } \\
\text { (kali) }\end{array}$ & 1.03 & 0.91 & 0.85 & 0.75 & 0.69 & 0.70 & 0.82 \\
\hline $\begin{array}{l}\text { Equity Multiplier } \\
(\%)\end{array}$ & $2.03 \%$ & $2.02 \%$ & $1.96 \%$ & $1.94 \%$ & $1.87 \%$ & $1.89 \%$ & $1.95 \%$ \\
\hline
\end{tabular}

Sumber : Annual report PT. Astra International Tbk., data diolah, periode 2012-2017.

- $\quad$ Net Profit Margin.

Selama periode 2012-2017, net profit margin PT. Astra International Tbk mengalami kenaikan dengan rata-rata $10.73 \%$. Pada tahun 2013 net profit margin mengalami penurunan sebesar $4.31 \%$ dibandingkan tahun 2012. Pada tahun 2014 net profit margin mengalami penurunan sebesar $4.47 \%$ dibandingkan tahun 2013. Pada tahun 2015 net profit margin mengalami penurunan yang lumayan besar yaitu sebesar $21.41 \%$ dibandingkan tahun 2014. Pada tahun 2016 net profit margin mengalami kenaikan lumayan besar yaitu sebesar $15.31 \%$ dibandingkan tahun 2015. Pada tahun 2017 net profit margin kembali mengalami kenaikan sebesar $15.30 \%$ dibandingkan tahun 2016. Hal ini menunjukkan bahwa perusahaan mendapatkan peningkatan keuntungan mulai pada tahun 2016. 
- Total Asset Turnover

Selama periode 2012-2017, total asset turnover PT. Astra International mengalami kenaikan dengan rata-rata 0.82 kali. Pada tahun 2013 total asset turnover mengalami penurunan sebesar 12.18\% dibandingkan tahun 2012. Pada tahun 2014 total asset turnover mengalami penurunan sebesar 5.68\% dibandingkan tahun 2013. Pada tahun 2015 total asset turnover kembali mengalami penurunan sebesar $12.18 \%$ dibandingkan tahun 2014. Pada tahun 2016 total asset turnover kembali mengalami penurunan sebesar 7.85\% dibandingkan tahun 2015. Pada tahun 2017 total asset turnover mengalami kenaikan sebesar $0.79 \%$ dibandingkan tahun 2016. Hal ini menunjukkan bahwa kemampuan perusahaan untuk menghasilkan uang dari total aset yang dimiliki baru mengalami peningkatan di tahun 2017.

\section{KESIMPULAN}

Hasil studi ini menemukan bahwa perusahaan memiliki kewajiban jangka pendek yang bagus karena memiliki aset yang lebih besar daripada kewajiban lancar, sehingga hutang jangka pendek perusahaan dapat dijamin oleh aset lancar yang dimiliki perusahaan serta semakin kecilnya modal yang dimiliki oleh perusahaan yang didanai dari pinjaman kepada kreditor. Perusahaan juga baru bisa menghasilkan laba dengan efisien mulai dari tahun 2016. Selain itu, PT. Astra International memiliki nilai market to book di posisi 2 terendah di tahun 2017 selama periode 2012 - 2017. Hal ini mengindikasikan bahwa perusahaan dikategorikan sebagai undervalued dan sangat baik untuk investasi jangka panjang, namun bisa juga mengindikasikan bahwa terjadinya penurunan kualitas dan kinerja fundamental emiten, sehingga dapat dilihat baik dari sisi analisa rasio maupun $d u$ pont, perusahaan memiliki kinerja keuangan yang baik. Hal ini sejalan dengan penelitian yang terdahulu yang pernah dilakukan terhadap kinerja keuangan perusahaan pada PT. Astra International Tbk periode 2007-2009.

\section{DAFTAR PUSTAKA}

Erica, Denny. (2018). Analisa Rasio Laporan Keuangan untuk Menilai Kinerja Perusahaan PT. Kino Indonesia Tbk. Jurnal Ecodemica, 2 (1), 12-20.

Fahmi, Irham. (2014). Manajemen Keuangan Perusahaan dan Pasar Modal. Edisi Pertama. Jakarta : Mitra Wacana Media.

Halim, Abdul. (2015). Manajemen Keuangan Bisnis Konsep dan Aplikasinya. Edisi Pertama. Jakarta : Mitra Wacana Media.

Harahap, Sofyan Syafri. (2013). Analisa Kritis Atas Laporan Keuangan. Cetakan Kesebelas. Jakarta : Rajawali Pers.

Hery. (2014). Analisa Kinerja Keuangan. Edisi Pertama. Jakarta : Grasindo.

Keown, Titman and Martin. (2014). Financial Management Principles and Applications. Twelve Edition. United States of America: Pearson.

Munawir, S. (2014). Analisa Laporan Keuangan. Edisi Keempat. Cetakan Kelimabelas. Yogyakarta.

Natan, Fredrik. (2010). Analisis Laporan Keuangan untuk Menilai Kinerja Keuangan pada PT. Astra International Tbk Periode 2007-2009. Akurat Jurnal Ilmiah Akuntansi, 1 (3).

https://repository.maranatha.edu/27/

https://www.astra.co.id/ 
